\title{
THE ANTITRUST TREATMENT OF ELECTRICITY MARKET OF UKRAINE: CONUNDRUM WITH THE CONCEPT OF COLLECTIVE DOMINANCE AND EU EXPERIENCE
}

\author{
Kseniia Smyrnova ${ }^{1}$, Anton Korynevych ${ }^{2}$ \\ Institute of International Relations, Kyiv National Taras Shevchenko University, Ukraine
}

\begin{abstract}
The main purpose of the article is to provide comparison research of collective dominance doctrine and practice in the EU and the enforcement practice in Ukraine. Methodology. The paper focused on the compliance of AMCU's analysis of national electricity market in Ukraine with the European law enforcement practice that arises from the international legal obligations of Ukraine to use in its practice the EU competition rules according to Article 18 of the Treaty establishing the Energy Community and taking into account the criteria of interpretation in accordance with the EU case law. Article 255 of the Association Agreement between Ukraine and the EU that clearly provides the principle of transparency, non-discrimination, and neutrality in compliance with the procedures of the procedural justice and the right of defence also indicates a special actuality of the carried-out research in this field. The main practical impact of such research is to implement not only substantial norms of the EU Competition law but its enforcement practice \& to introduce it within the practice of AMCU. Value/originality. The paper examines a dominance doctrine, market power definition, economic strength, and collective dominance practice in the EU enforcement practice. A special attention was paid to enforcement practice in the electricity market. Due to the fact that the investigation of Ukrainian electricity market was provided for the first time in Ukraine, there is no practice yet in this issue. This causes the necessity of wide comparative approach in the principles of collective dominance in the electricity market in Ukraine. Results. The paper finds that the AMCU's approach to electricity market regulation in Ukraine confirms the necessity to reform the system of the governmental regulation in the wholesale electricity market and in the market of services for electricity transmission, necessity for the change of the system for tariff and pricing policy formation on the part of the National Energy and Utilities Regulatory Commission of Ukraine and the Ministry of Energy and Coal-Mining Industry of Ukraine for developing the competition in electricity market and the need to follow the approaches and criteria of the EU competition law with regard to determination of the dominance in the market, which is stipulated by the international legal obligations of Ukraine arising from Articles 18 and 94 of the Treaty establishing the Energy Community and Art. 255 of the EU-Ukraine Association Agreement.
\end{abstract}

Key words: competition; collective dominance; EU; Ukraine; Anti-Monopoly Committee of Ukraine; wholesale electricity market.

\section{JEL Classification: K21, K23}

\section{Introduction}

Current wholesale electricity market of Ukraine is, first of all, a unified, well-ordered centralized system of relationships between undertakings on the purchase and sale of electricity. The main legal and organisational principles regulating the general conditions of current wholesale electricity market of Ukraine functioning are provided for in the Constitution of Ukraine, the Law of Ukraine "On Electricity Industry" (as amended), the Judgment of Constitutional Court of Ukraine dated February 12, 2002№ 3-pп/2002 (the electricity industry case), the regulatory acts of the President of Ukraine, the Cabinet of Ministers of Ukraine, the National Energy and Utilities Regulatory Commission of Ukraine (hereinafter referred to as the NEURC). The Wholesale Electricity Market (WEM), which is a well-ordered system for the electricity purchase and sale transactions, has already been functioning in Ukraine for over fifteen years. At that, this market is under strict centralised governmental control and regulation. The governmental regulation of the energy market is carried out by the National Energy and Utilities Regulatory Commission 
of Ukraine (NEURC), basic responsibilities of which are: licensing and regulating the activities of natural monopoly companies; promotion of the development of competition in spheres of electricity and heat energy production and supply; adopting the pricing and tariff policy, protecting the consumer's rights, implementing the electricity usage regulations.

Ukraine is a member of the Energy Community and has to fulfil the obligations concerning the implementation of the acquis, particularly in the electricity industry. In particular, Art. 18 of the Treaty establishing the Energy Community provides for the adherence of competition rules in this market (detailed in Appendix III and actually being a reproduction of the competition rules of the EU now contained in Art. 101, 102, 106, and 107 TFEU.

Thus, the EU competition principles became the part of the Ukrainian legislation, which is explicitly stipulated in the international treaty, which was agreed to by the Verkhovna Rada of Ukraine by the ratification of the Treaty establishing the Energy Community. The basis of legal regulation within the Energy Community for Ukraine is the EU law, which should be implemented in the law of Ukraine in accordance with the obligations under the international law stemming from obtaining full-fledged membership in the Energy Community since February 1, 2011.

Due to the EU exclusive competence of legal regulation of competition (Art. 3 TFEU); national competition authorities and national courts have to coordinate their law enforcement practice and apply Art. 101-109 of TFEU and Regulation No. 1/2003 in a unified manner.

However, not only the national legislation of the member states but also that of the countries launching a free-trade area with the EU must comply with the EU principles of competition (Smyrnova, 2015). However, the standard practice of implementing the competition rules and unified rules of interpretation of the EU competition rules are inherent not only for the Member States but also for the countries to have entered into association agreements with special provisions on competition within free-trade areas and as a part of the sectoral cooperation of the EU, in particular, the participant countries of the Energy Community. It is expressly emphasized by Art. 94 of the Treaty establishing the Energy Community.

The EU-Ukraine Association Agreement (AA) also provides for ensuring an effective competitive environment within the established free-trade area (Art. 253-267) and reproduces the regulations of the EU law and contains provisions strictly referring to the regulations. So, EU common rules concerning the internal energy market apply to Ukraine. At the same time, the Association Agreement determines the compliance between its provisions and the provisions of the Treaty establishing Energy Community, giving priority to the rules of the latter in case of conflict between them. Accordingly, the regulations of the Association Agreement cannot contravene the EU law, which is used in compliance with the provisions of this Agreement.

Upon implementing the provisions of the Association Agreement regarding the cooperation of the parties in the energy industry, the parties assume the obligation to give a priority to the legal or other acts complying with the Treaty establishing Energy Community and the effective EU law in this field. The compliance assessment should take into account all the decisions approved under the Art. 91 of the Treaty establishing Energy Community (Art. 278 of the EU-Ukraine AA).

In this way, it should be mentioned that not only the legislative and law enforcement practice of European institutions but also the practice of the EU Court should be implemented in the work of the national authorities of Ukraine (Smyrnova, 2014) since it is the court judgments where the unified law enforcement practice of the EU is reflected.

Furthermore, according to p. 3, Art. 255 of the EU-Ukraine Association Agreement, parties have taken obligations to use their competition law in a transparent, timely, and non-discriminatory manner. The transparency principle by nature reflects clarity, obviousness and comprehensibility without doubt or ambiguousness. There is no arguing that transparency is one of the fundamental principles of trade regulation (Berezovska, 2015).

Furthermore, one of the fundamental principles of competition rules' implementation is its nondiscriminatory manner with preserving the principle of procedural fairness and right of defence, which is also clearly stipulated in paragraph 3, Article 255 of the Association Agreement.

Thus, it can be stated based on the above mentioned that the competition in the electricity market in Ukraine should develop in observance of the EU competition law, which is provided for in Art. 18 of the Treaty establishing the Energy Community, and with the rules of interpretation being used, which comes from the EU judicial practice (that is, the case law).

So, it seems necessary to determine the level of observance of the European law enforcement practice in the practice of the Ukrainian competition authority and the observance of the international obligations to be committed to the principle of transparency, nondiscrimination, and procedural fairness provided for in Art. 255 of the Association Agreement.

The Anti-Monopoly Committee of Ukraine (AMCU) on 24 December finished the special investigation of the market \& on 1 June 2016 presented a Report on the investigations provided during August-December 2015 into this sector of the economy (wholesale electricity market) that was the first in-depth analysis of this market (Report). Under this Report, AMCU 
stated on the dominant position of Energorynok SE as a sole purchaser and collective dominance of three undertakings on the basis of summing their shares. The main aim of the article is to analyse in a comparative manner the concepts of obstacles \& criteria on assessment of relevant market, dominance and the concept of collective dominance in the EU.

\section{Market model and effects-based analysis and the concept of dominance}

In the EU, the market definition is important for all spheres of competition law (Art. 101, as well as 102 of TFEU and the Merger Regulation application), but the approach to market definition differs depending on the behaviour type where the relevant market is to be defined (Case T-62/98, Volkswagen AG v. Commission). The Commission Notice on relevant market (1997), as it was specified in the case Amman \& Sohne, serves as a tool to increase the transparency of the activities of the EU Commission and strengthen the consistency of its decision-making (Case T-446/05 Amman \& Sohne $\mathrm{GmbH} \& \mathrm{Co} \mathrm{KG}$ v Commission).

AMCU inattentively analysed the relevant market and its Report contains data concerning the electricity sold in the WEM, data concerning the generating capacities of the WEM and detailed data on the volume of the coal market. At the same time, there is no justification for the inclusion of the coal market into the analysis of nationwide electricity market. There are no key findings on generation, wholesale, firsttime sale (first level of supply) and retail. These data do not allow for determining the product boundaries of the nationwide electricity market. There are only ascertaining conclusions about the separation of the generation market, the wholesale electricity market, and the electricity transmission service market. The influence of the wholesale electricity market on the generation market and their mutual dependence are not studied, and no conclusions are given in this regard. At the same time, despite AMCU states the existence of the retail market and the formation of final demand for electricity there, it has not provided the assessment of the influence of the retail market on the formation of volumes and prices on electricity as a product in the electricity generation and wholesale electricity markets. In the absence of a liberalised electricity market in Ukraine and the peculiarities of price and tariff formation for this product type on a non-competitive basis, particularly due to the governmental regulation (fixation) by NEURC of the tariff policy, the AMCU should justify the product boundaries of the market more elaborately.

Moreover, we can stress that the definition of relevant product market cannot be based solely on econometric calculations. Other elements, namely the physical characteristics of the product or the sphere of its application, have to be taken into account. The following factors are considered in the determination of the product market boundaries: the prices of products; the physical characteristics of products and services; the purpose of products and services; consumers' preferences. In accordance with the EU practice, the Commission uses economic instruments based on quantitative indicators to elaborate its analysis of determining the market boundaries. They include price correction analysis (case Arsenal/DSP), critical analysis of loss (case INEOS/Kerling) and demand evaluation (cases Unilever/Sara Lee, Kraft/Cadbury).

The concept of the dominant position itself is not defined in the TFEU. The definition given by the EU Court in the United Brands case is constantly quoted in the majority of EU Commission decisions and Court judgments concerning the implementation of Art. 102 of TFEU. The EU Court has defined that it is "a position of economic strength enjoyed by an undertaking which enables it to prevent effective competition being maintained on the relevant market by giving it the power to behave to an appreciable extent independently of its competitors and ultimately of its consumers" (Case 27/76 United Brands ).

The definition of the dominant position according to the EU law was given by the EU Court in the Continental Can case: undertaking holds the dominant position when it has a power to behave independently, which lets them act without regard on their competitors, customers, and sellers. It is situation when they, due to their market share or their market share together with ownership of technological knowledge, raw material resources or capital, have the power to set prices or control the production or distribution of a significant portion of the relevant product (Case 6/72 Europeembellage Corp and Continental Can Company Inc. v. Commission).

Later the EU Court has confirmed and extended this definition in the Hoffman - La Roche case: "An undertaking, which has a very large market share and holds it for some time..., - is by virtue of that share in a position of strength, which makes it an unavoidable trading partner and which, already because of this secures for it, at the very least during relatively long periods, that freedom of action which is the special feature of a dominant position" (Case 85/76 Hoffmann-La Roche \& Co. v. Commission)

The concept of dominance consists of three basic mutually related elements: (a) there must be a position of economic strength on a market which (b) enables the undertaking(s) in question to prevent effective competition being maintained on that market by (c) affording it the power to behave independently to an appreciable extent.

Firstly, dominance exists in relation to a market; it cannot exist in the abstract. It also implies that an undertaking either on its own or together with other 
undertakings must hold a leading position in that market compared to its rivals either independently or jointly with other enterprises. The second and third elements concern the link between the position of economic strength held by the undertaking concerned and the competitive process, i.e. the way in which the undertaking and other players act and interact on the market.

Both practice and doctrine prove that the size of the market share is not defined in the definition of dominance. This aspect differs significantly from the formalized legislative approach of Art. 12 of the Law of Ukraine "On Protection of Economic Competition", where the analysis of the existence of market power is weakly defined narrowed to the right of undertakings to prove that they are subjected to competition. Ability to act independently from one's competitors, customers and consumers is the significant distinctive feature of this concept. Besides, both the EU Commission and EU Court, while defining the dominant position, pay a special attention to how effectively the enterprise blocks the competitors entering the market, what is its market share, what is its economic potential and access to the market.

Accordingly, while studying the electricity market and the features of the dominant position, the AMCU should have studied and justified the market power of undertakings, the undertakings' opportunities to act independently from their competitors, consumers, suppliers, and customers, the opportunity of these undertakings to prevent effective competition and to establish and maintain prices above the competitive level.

The fact of the dominant position in the market is proven by detecting the relative share of the monopolist by establishing the fact of existing monopolist's contractual relations with potential competitors (rivals); a special system of relations with customers and suppliers not complying with the principles of fair competition in the relevant market. On determining the dominance in the market, the financial potential of a monopolist, the lack of competitors, the existence of potential dependence of third parties on the monopolist are taken into account. Among other factors taken into account on the definition of the dominant position are the following: the proportion of shares of the enterprise and its closest competitors, the technological advantage of the enterprise over its competitors, the existence of a highly developed sales system and the lack of potential competitors. However, while studying all of these factors, their relation to the above elements of the dominant position must be considered (market power, competition prevention etc.); i.e. not only certain features or factors should be highlighted but also the examination whether they actually result in a market power of the undertaking must be carried out.

Procedurally, the abuse of dominant position examination is usually performed by the EU
Commission and then can be reviewed by the EU Court. According to Art. 102 of TFEU, one more issue has to be considered: if an enterprise occupies the dominant position, how significant is its market share? Some part of the market may only be controlled in terms of supplies of a certain type of products or services. This is why it is important to determine the product market. As was established in the Continental Can case, the definition of the market is crucial for the assessment of dominant position, as "the relevant market is of essential significance, for the possibilities of competition can only be judged in relation to those characteristics of the products in question by virtue of which those products are particularly apt to satisfy an inelastic need and are only to a limited extent interchangeable with other products" (Case 6/72 Europeembellage Corp and Continental Can Company Inc. v. Commission). That is extremely significant that the ECJ has annulled the Commission decision in this case due to the lack of arguments and evidence regarding the definition of the relevant market. The ECJ also supports the approach according to which "... the separation of the market object allows for establishing the space within which certain competition conditions are functioning and a predictable dominant enterprise is operating" (Case C-7/97 Oscar Bronner GmbH \& CoKG v Mediaprint).

Unlike the Ukrainian law, there are no certain mathematical criteria of dominance definition fixed in the EU. Many criteria, on the basis of which the decision is made, are considered in each specific case. However, the market share of the monopolist has to be rather large, usually over 50\% (Sufrin, 2014; Blanco, 2012; Monti 2006).

At the same time, according to the European practice, the existence of a large enterprise in the market does not mean that it occupies the dominant position at all. An enterprise gains the dominant position if it can act in the market of the specified product independently from its competitors. In other words, an enterprise occupies the dominant position if it has market power. The market share possessed by the enterprise serves as the first indicator for the consideration of the market dominance issue. If the enterprise possesses a relatively small market share, its position, naturally, cannot be dominant. In this regard, the Commission establishes roughly that the size of the share under $40 \%$ is unlikely to be an indicator of market dominance (DG Competition discussion paper on the application of Article 82 of the Treaty to exclusionary abuses, 2005).

Barriers to market accessing are another important factor that allows defining the existence of dominance. Sorrowfully the AMCU, on defining the barriers to market access, did not apply the existing experience of the European Commission and the EU Court regarding the definition and assessment of market barriers and their influence on competition and market power of market participants; in particular, the influence of 
electricity import on competition was not taken into account, and the existence of economic barriers for market entry and their influence on the market power were not justified economically. The existence of such barriers actually, factors leading to their appearance, the influence of these barriers on competition level in the market and the activity of the market participants, their leading to appearance or absence of market power were not analysed.

While analysing the position of single customer (SE Energorynok) in the nationwide electricity market, legislative features of pricing by NEURC with authority to control over the pricing in electricity market, and the authorities of the Ministry of Energy and Coal-Mining Industry of Ukraine (hereinafter referred to as Ministry of Energy and Coal) and the restrictions containing in the law of Ukraine regarding the freedom to act and independence in decision-making of SE Energorynok should be considered.

Under such legislative conditions, it is better to say that the monopsony of SE Energorynok in the electricity market is of a limited nature provided by the existing market model and the regulatory legal acts governing the relations in this market. In this way, the Committee should not declare the monopoly of SE Energorynok based only on the fact that it occupies a $100 \%$ share of the market, and the functions and role of SE Energorynok not only as the "unified customer" but also as an element of the institutional monopoly of the state represented by the authorities defining the conditions of product turnover in this market should be studied. Such an approach will comply with the main principles of defining the dominant position in the EU law, according to which the market share is not defined, and other factors defining the position of the undertaking in the market should be studied as well.

\section{Judicial interpretation of collective dominance concept in the EU}

The EU law theory and practice define the following three conditions, which give grounds to state the existence of collective dominance present:

1) each entity of collective dominance shall be able to obtain at low cost the information on the behaviour of other entities of collective dominance;

2) members of collective dominance shall have an influence on the undertaking, which: in case of any agreement between them - restricts competition, and in case of coordinated actions - deviates from the general policy at the given market;

3) the expected reaction of competitors, both existing and potential, shall not have any noticeable effect on expected results of coordinated actions (general policy of collective dominance of members in the target market).

Moreover, as further analysis of the EU judicial practice shows, the necessary conditions of collective dominance are also relations between the members of such dominance, joint policy on the price increase, etc., which allows them to act as a "single" economic unit in relations with customers.

Art. 102 of TFEU refers to the abuse of collective dominance condition by one or more undertakings. The EU Court of Justice (Cases C-395/96 P and C-396/96 P of Compagnie Maritime Belge Transports, Compagnie Maritime Belge and Dafra-Lines v. Commission) established two stages necessary for collective dominance: establishing the fact of collective entity existence, and proving that the undertaking has a dominant position in the market. Collective dominance can be performed by two or more undertakings that are legally independent of each other, provided that they are a collective undertaking from an economic point of view or act together as one in a particular market. It is necessary to establish economic relations or factors that may contribute to such relations. Economic assessment and, in particular, evaluation of the relevant market structure is of significant importance. Apparently, this judgment extended the concept of collective dominant position by taking into account potential opportunities that have not yet appeared quite clearly, however, it is another demonstration of a tendency to substitute formal legal criteria for an economic approach. Therefore, this case has settled such necessary element of collective dominant position as legal and economic relations between the members of collective dominance confirming that these undertakings can act as a single "collective" undertaking, adopt a joint policy, and perform the collective market behaviour, particularly, in respect of prices.

In case of collective dominance, the approach of the EU Commission to the definition of interrelationships in the group, which was applied in the case of France v Commission (Cases C-68/94 and C-30/95), was also supported in subsequent cases, in particular, the case of Gencor (Case T-102/96), in which the EU Court of Justice has found that "the relationship of interdependence existing between the parties" creates potential coordination between them in sense of forming collective dominance. In case of Airtours (Case T-342/99), the EU Court of Justice established that the collective dominance exists, where each member of the collective dominant entity applies the conscious joint policy in the market on a long-term basis in order to sell without entering into any agreement or act jointly in the meaning provided for in Art. 101 of TFEU. This test was applied by the Commission and the EU Court under conditions of high liberalisation of the market with established transparent competitive market conditions and under conditions of information exchange, as well as the inability of sellers and consumers to influence the market.

All of the abovementioned cases reflect the behavioural approach of the EU Commission on 
defining the collective dominance (Petit, 2013; Monti, 2001). The European competition law doctrine, which is the basis for positions of the EU Commission and the EU Court, states that structural analysis of the market is not sufficient for collective dominance analysis. A behavioural component, in this case, shall be the critical factor (Joilet, 1970). Other scientists stated that the EU Commission shall prove the fact of coordinated (parallel) behaviour of the participants while justifying the fact of collective dominance, otherwise, national competition authorities shall refrain from the collective dominance regime (Mezzanotte, 2010).

In cases of collective dominance, not only the amount of quantitative indicators of the corresponding market shares is calculated. Market share is not the only or critical factor in the search for a dominant or collective dominant position (Alison and Sufrin, 2014). Bright example is the judgment of the EU Court in case of French Republic and Société commerciale des potasses et de l'azote (SCPA) and Entreprise minière et chimique (EMC) v Commission, where it was proved that the market shares of two independent enterprises in amount of approximately $60 \%$ cannot conclusively mean the existence of a collective dominant position (Cases C-68/94 and C-30/95). In case of Airtours (Case T-342/99), the EU Court developed a threelimbed structural test for determining collective market dominance. Firstly, each firm knew how other members were behaving (they could monitor the market to see if they were adopting possible policy changes); secondly, there should be evidence of tacit coordination, which is stable and is observed for a long time (i.e., there was no incentive to depart from the common policy on the market); and thirdly, the foreseeable reactions of competitors (actual and potential), as well as consumers and clients would not jeopardise the results expected from the generally accepted policy.

However, in its judgment in the case of Impala (Case T-464/04), the EU Court not only confirmed the existence of these three criteria for identifying collective dominance but also clearly stated the need to attach evidence to these criteria and characteristics of the market. Definition of such criteria is a result of considering collective dominance in previous cases. Thus, in particular, in the case of TACA (Commission Decision of 16 September 1998, IV/35/134) the Commission analysed the relationship between enterprises in terms of their coordination of actions for the analysis of collective dominance. Later in the same case, the EU Court clearly stated that in order to prove collective dominance in the market, there must be proofs of the "factors of economic correlation between the enterprises" (Cases T-191/98, T-212 - T-214/98 Atlantic Container Line $\mathrm{AB}$ and Others v Commission).

Moreover, these criteria have been repeatedly used by the EU Court in various cases for collective dominance. At the same time, the European practice also notes that such necessary element as coordination of actions of participants (collusive effect) within the collective dominance may take various forms, such as forms of direct coordination of a pricing policy.

Currently, in the energy domain, both European doctrine (Scholz, Purps, 2011) and European court practice are common in compliance with such criteria as the enterprises in this group shall be connected in such a way that they adopt the same behaviour in the market. The mentioned above confirm that the fact of collective dominance can be proved only on the basis of parallel cooperation. Moreover, the European Court took this position in one of its last judgments in case of Laurent Piau (Case T 193/02). During the analysis of the doctrine and national laws of the EU member-states, it is also possible to assert that there is a synchronisation of approaches between the European Court and national competitive agencies. Consequently, the most widespread evidence of collective dominance is the evidence of the close parallel behaviour.

However, while applying Article 12 of the Law of Ukraine "On Protection of Economic Competition," the AMCU ignored the legislation requirements that the dominance position of an undertaking in a market should be determined using the criteria applied to determine such dominance position under the EU Law, in particular, in the practice of law enforcement and judicial practice in the EU.

It is essential to note that the behavioural aspect of any collective dominance also appears from the analysis of provisions content of Articles 1, 12 of the Law of Ukraine "On Protection of Economic Competition" and of Methodology provisions concerning the determination of the monopoly (dominating) position of undertakings. In particular, paragraph 5 of Art. 12 of the Law of Ukraine "On Protection of Economic Competition" is a special qualifying provision characterising such a situation on market when, in contrast to the individual dominance of a separate undertaking, the ability to determine or fundamentally influence the conditions of goods turnover in the market belongs to an undertaking not independently but jointly with other undertakings in other words, to aggregate undertakings as a collective entity.

Provision of Article 12 also indicates the fact that the aggregate part, namely formed jointly (but not cumulative, i.e. the part obtained arithmetically), of undertakings is a structure coefficient, on the basis of which any determination of dominating position shall be based. It means that exactly the taken together undertakings - so-called "an entity of collective dominance" - possess this market (monopoly) power and this power is present exactly thanks to their common (joint) behaviour. The object for analysis, in this case, is "entity of the collective dominance" and its market power as a collective entity that acts, versus other participants of the market and at that exactly due 
to such an integration a collective entity (i.e. thanks to the aggregated market power of all members of the collective entities that is demonstrated in a specified coordination and similarity, parallelism of competitive behaviour among them) has a possibility to obtain any uncompetitive advantages, determine conditions of goods turnover or block, limit the competition, in particular, increase the prices, which would be impossible individually for each separate undertaking that is a part of collective dominating entity.

\section{Conclusions}

According to European experts (Chauve \& others, 2009), the electric energy sector in whole is characterised by its uniformity (homogeneity) with a low elasticity of demand, which deprives the customers of usual instruments to regulate prices and supplies. In respect of the supply, it is also characterised by significant discrepancies between expenses for the implementation of different manufacturing technologies that are not reflected in the price formation of the supplier.

During 2003-2004, The EU Commission carried out the study of electricity market in the EU (according to the data of six member-states - Germany, France, Netherlands, Belgium, Spain, and Great Britain (excluding North Ireland) and a public well-grounded detailed analysis of this market was presented with involving of leading expert centres of Europe. However, during the study of the electricity market in Ukraine, the AMCU has not considered the experience of carrying out such studies in the EU since the principles, data retrieval, description of the principles and approaches used by the European experts are absent in studies of the AMCU. It can be conditioned by the short timing of performing the study, usually such studies in the EU are carried out for several years, and in case the investigations of an antimonopoly body shall be prepared within a shorter period, a well-grounded study of competition carried out by the regulatory authorities in the field of the electricity industry and the expert community precedes it. But it does not cancel the groundlessness and the hasty conclusions of the AMCU that in fact conflict with the concept of "collective dominance" in the EU law.

In the European practice, there are single cases connected with the competition rules in the electricity market. Most of them have relation to the concentration and state aid procedures. However, some of them also concerned abuse of the dominant position. In this connection, it is essential to refer to the analysis of case E.ON (2008).

So, taking into account an approximate parallelism with the report of AMCU, it is essential to appeal one more time to the analysis and to the well-grounded study of the national electricity market that was not carried out in fact. Besides, in the existing model of
WEM (wholesale electricity market) of Ukraine, the AMCU cannot be confined only to import and electricity generation market (wholesale market) as in case E.ON, but it shall carry out a study of all the elements of the wholesale electricity market in Ukraine taking into account interdependence and influence of all its elements on each another.

Considering the fact that the national electricity market of Ukraine is set at the legislative level, separation of its single components shall be carried out in the process of studying their interdependence and analysis of the market power that does not belong to the manufacturers of electricity as a result of significant government regulation of this sector of the economy. At the same time, AMCU has not yet studied this aspect in relation to SE Energorynok (state enterprise) that not only integrates the functions of the unified wholesale buyer and supplier but acts as a system formative element of market functioning being the disposer of payments system, spending unit of WEM, the settlements centre, main operator of the electricity commercial accounting system in the regimented limits of AWEMPs between the members of the wholesale electricity market of Ukraine and appendices to them.

The national electricity market is in fact an aggregate of commodity markets reflecting the relationships, which arise from the functioning of the united energy system of Ukraine and are economically structured according to the AWEMP into the WEM system that is characterised by the state of institutional monopoly depriving the participants of the market power as a result of governmental control and the conditions of the goods turnover in the market are specified by the public authorities. The "single buyer" market model is combined with government regulation represented by State Enterprise "Energorynok" and the National Energy and Utilities Regulatory Commission of Ukraine (NEURC) leads to the conclusion about actual absence of the market power of electricity producers and consequently the absence of a level of independence required for determining the dominance position according to the EU Law.

According to the European practice, it is possible to conclude that the AMCU report and conclusions on the collective dominance do not cover the analysis of conditions, under presence of which there are grounds for determination of the collective dominance, in particular: i) conditions under which every undertaking, which is a part of collective dominance, shall have a possibility to easily obtain information concerning the behaviour of other undertakings in the market; ii) conditions under which the collective dominance participants shall have the possibility to influence the undertaking, which: in case of agreement between them - can restrict the competition and in case of coordinated activities avoids the common policy in this market; iii) conditions under which the expected reaction of competitors both 
acting and potential shall not significantly influence the expected result of agreed actions (the common policy implemented by collective dominance participants in the targeted market); iv) conditions under which economic, legal, and structural links providing an opportunity to implement the joint policy in particular, concerning the prices are present between the collective dominance participants; v) conditions under which the collective dominance participants possess the market power, i.e. can act independently from buyers, customers, and competitors. It is obvious that the sufficient link or connection between the undertakings should be the core concept of the case analysis.

According to the words of Dr. J. Lubkin, Head of Unit of unit B1 of the European Commission's Competition Directorate-General, in charge of Antitrust in the field of Energy and Environment (2015), the most important factor for analysing the competition in the electricity market are particular features of the market structure and high barriers for market entry together with particular "unique" price-making mechanism in electricity markets. Accordingly, one of the essential elements of the collective dominance is the influence of its participants on the price. Consequently, according to the EU law, if participants of collective dominance do not have a possibility to influence the price there will be no collective dominance even without consideration of issues of dependences between such participants. In this connection, the AMCU should reflect this aspect of EU law enforcement practice in its Report.

On the basis of abovementioned, it is possible to conclude that the liberalization of electricity market that was started in the EU in the middle of 90th of the XX century was carried out through the relevant stages of supranational and national legislative regulation. The latest examples of the law enforcement practice in the field of compliance with the competition rules in the EU show that they became a basis for a new approach that was reflected in the adoption of the third package for the electricity market liberalization. So, the practice and the approaches of the European Commission were and remain targeted at the market liberalization, decrease of the regulatory influence and development of competitive relationships.

Due to the fact that the national electricity market of Ukraine is strictly determined in the legislation, any allotment of its separate elements shall be carried out together with the research of their dependences and analysis of the market power of all participants that take part in this market relations and, first of all, of public regulatory authorities. So, the statement about the collective dominance without proving the existence of coordinated policy and parallelism is superficial taking into account the fact that the parties are in the limited legislative field in respect of electricity demand and supply pricing, the policy in respect to which is formed unilaterally by the NEURC.

The need to change the structural state regulation of the wholesale electricity market and to change the legislative fixing of pricing and control over the pricing become the main factors for changing the energy market regulation.

Consequently, the AMCU's approach to electricity market regulation in Ukraine confirms the necessity to reform the system of the governmental regulation in the wholesale electricity market and in the market of services for electricity transmission, necessity for change of the system for tariff and pricing policy formation on the part of the National Energy and Utilities Regulatory Commission of Ukraine and the Ministry of Energy and Coal-Mining Industry of Ukraine for developing the competition in electricity market and the need to follow the approaches and criteria of the EU competition law with regard to determination of the dominance in the market, which is stipulated by the international legal obligations of Ukraine arising from Articles 18 and 94 of the Treaty establishing the Energy Community and Art. 255 of the EU-Ukraine Association Agreement.

\section{References:}

Alison J., Sufrin B. (2014). EU Competition Law, Fifth Edition, Text, cases and materials. Oxford University Press, 305.

Berezovska I.A. (2015). Koncipciya prozorosti v Ugodi pro asociaciyu mizh Ukrainoyu ta ES [The concept of transparency in the Association Agreement between Ukraine and the European Union]. Law of Ukraine, 8: 53-64. (in Ukrainian)

Council Regulation (EC) No 139/2004 of 20 January 2004 on the control of concentrations between undertakings (the EC Merger Regulation) (2004) Official Journal, L 024:1 - 22.

Council Regulation (EC) No.1/2003 of 16 December 2002 on the implementation of the rules on competition laid down in Articles 81 and 82 of the Treaty (2003). Official Journal, L 1:1-25.

Joilet R. (1970). Monopolisation and abuse of dominant position - a comparative study of the American and European approaches to the control of economic power, The Hague: Martinus Nijhoff, 1970, 239-245.

Mezzanotte F. (2010). Using Abuse of Collective Dominance in Article 102 TFEU to Fight Tacit Collusion: The Problem of Proof and Inferential Error. World Competition, 33(1): 77-102.

Monti G. (2001). The Scope of Collective Dominance Under Article 82, Common Market Law Review, 38: 131-139.

Monti G. (2006). The Concept of Dominance in Article 82, European Competition Journal, 2(31): 45-46.

Ortiz Blanco L. (2012). Market Power in EU Antitrust Law. Hart Publishing. 
Vol. 4, No. 1, 2018

Petit N. (2013). Collective dominance as effective tacit collusion in Handbook on European Competition Law, substantive aspects, Edward Elgar, 325-332.

Philippe Chauve, Martin Godfried, Kristóf Kovács, Gregor Langus, Károly Nagy, Stefan Siebert (2009). The E.ON electricity cases: an antitrust decision with structural remedies, Competition Policy Newsletter, 1: 51-54.

Scholz U., Purps S. (2011). The application of EC Competition law in the Energy Sector, World Competition, 34: 449.

Smyrnova K. (2014). Enforcement of Competition Rules in the Association Agreement between EU \& Ukraine, Yeabook of Antitrust Regulatory Studies, 7(10): 263-278.

Smyrnova K.V. (2011). The European integration of Ukraine: topical issues. Law of Ukraine. No. 5: 148-152.

Smyrnova K.V. (2015) Implementaciya polozhen pro konkurenciyu v Ugodi pro asociaciyu mizh Ukrainoyu ta ES [The implementation of the competition provisions in the Association Agreement between Ukraine and the European Union], Law of Ukraine, No. 8: 75-82. (in Ukrainian)

Smyrnova K.V. (2015). Pravovui poryadok konkurenciivES (novitnitendencii rozvutku) [The legal order of competition in the European Union (newest trends of development)] (Dr. Jur.Sc.), Kyiv: Taras Shevchenko National University of Kyiv: 40 pp. (in Ukrainian)

The Law of Ukraine "On Ratification of the Protocol on Ukraine's accession to the Treaty establishing the Energy Community" of December 15, 2010, No. 2787-VI (2011). Official Bulletin of Ukraine. No. 1. art. 13.

The Law of Ukraine "On the Ratification of the Association Agreement between Ukraine, on the One Part, and the European Union, the European Atomic Energy Community and Their Member States, on the Other Part" (2014). Gazette of the Verkhovna Rada of Ukraine. No. 40: 2021.

The text of AMCU's presentation of the Report (2015) (text available only in Ukrainian, there is no English version of the Report) Retrieved from: http://www.amc.gov.ua/amku/doccatalog/document?id=125980\&schema=main (accessed 28.03.2018).

Vickers J. (2006). Market Power in Competition cases, Competition Law Journal No2 (3):11. 